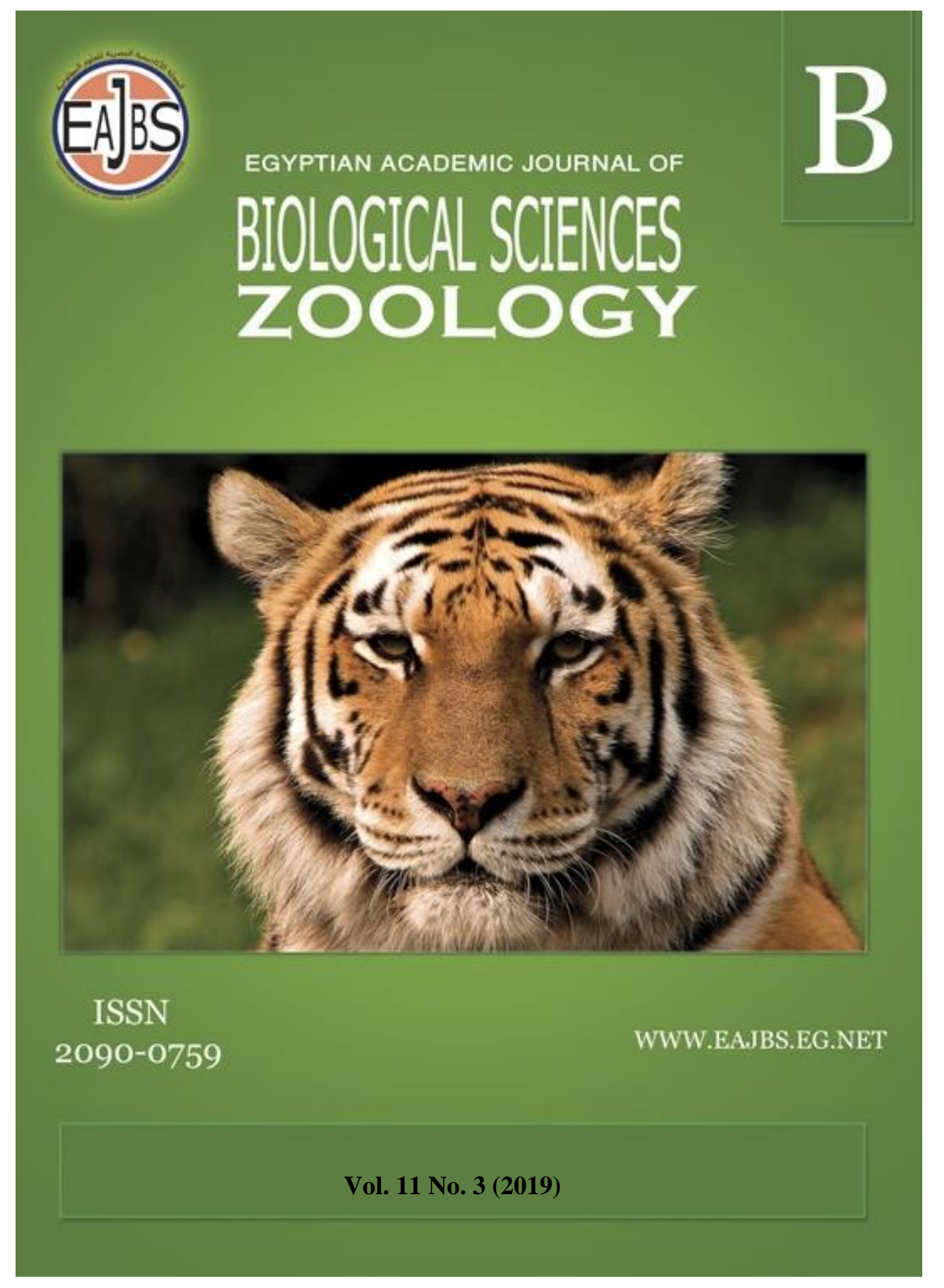

\footnotetext{
Citation: Egypt. Acad. J. Biolog. Sci. (B. Zoology) Vol. 11(3)pp 169-179 (2019)
} 
Egypt. Acad. J. Biolog. Sci., 11(3): 169- 179 (2019)

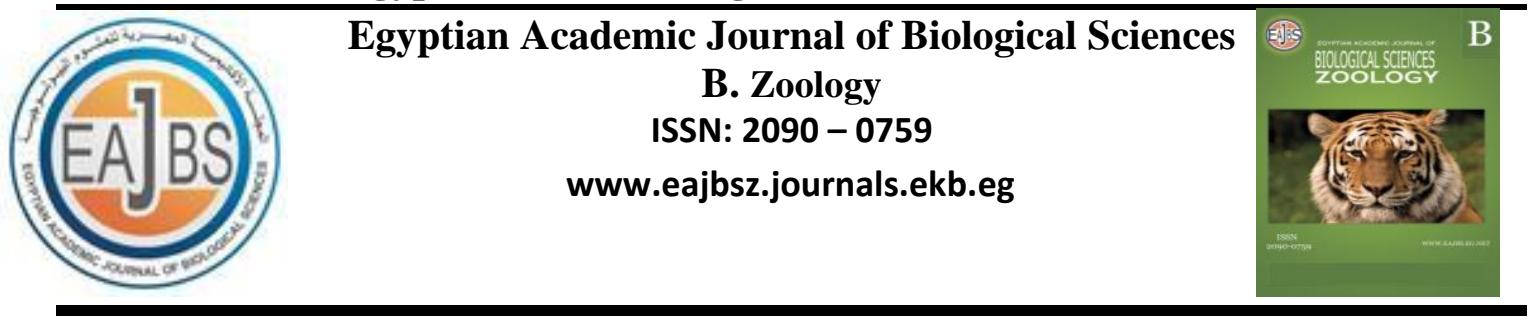

\title{
Morphological Effects of Pollution on Gill of Common Clam, Tapes decussatus Linnaeus, 1758 (Bivalvia: Veneridae)
}

\author{
Dalia S. Hamza ${ }^{1 \& 2}$ \\ 1-Department of Biology, College of Science, Jouf University, Sakaka 2014, Saudi \\ Arabia \\ 2-Department of Zoology, Faculty of Science, Benha University, Benha \\ 13518, Egypt \\ E.Mail: dshamza@ju.edu.sa - dalia.hamza@fsc.bu.edu.eg
}

\begin{tabular}{l} 
ARTICLE INFO \\
Article History \\
Received:29/10/2019 \\
Accepted:15/12/2019 \\
\hline Keywords: \\
Bivalvia, \\
Veneridae, Tapes \\
decussatus, Filter- \\
feeding, Gill, \\
Pollutants, \\
Scanning Electron \\
Microscopy.
\end{tabular}

ARTICLE INFO

Article History

Received:29/10/2019

Keywords:

Bivalvia,

Veneridae, Tapes

decussatus, Filter-

feeding, Gill,

Pollutants,

Microscopy.

\section{ABSTRACT}

Bivalves have been widely used as bioindicators of aquatic habitats because their filter-feeding habit leads to the accumulation of pollutants from the environment. Tapes decussatus is a common edible venerid clam bivalve in Egypt and has particular importance because its habit of penetrating sea sediments can provide information about the surrounding environment. Gill filaments have a large surface with constant contact with water and are therefore used to monitor aquatic environments. In this study, total hydrocarbons and heavy metals were shore (Marsa Matrouh) and measured in two sites of Egypt, Cleopatra Port of Suez (Suez); scanning electron microscopy (SEM) was used to examine the morphology of Tapes decussatus gill filaments and to compare the gill structure in specimens from the two sites. Cleopatra site presents low levels of heavy metals and hydrocarbons undetected, whereas Port of Suez site recorded high levels; because it was directly affected by industrial discharges and harbor pollutants. The gill filaments of $T$. decussatus have three types of cilia; frontal cilia, laterofrontal cilia, and lateral cilia. Structures joining the inner and outer gill lamellae were found on the abfrontal surface. By comparing the gill of the clam from the two sites; there was an aggregation of particles on the ostia, appearance of bacterial communities at the abfrontal surface of gill fillaments and accumulation of mucus on the frontal surface of the gill filaments of specimens which collected from Suez Port site.This mucus may function as a protective barrier against pollutants.

\section{INTRODUCTION}

The existence of pollutants in marine environments is a concern for the health of living organisms and can lead to the accumulation of toxic substances in organisms and food webs (Stewart et al., 2004). Toxic substances in marine environments are evaluated through chemical monitoring, including biological monitoring (Garrigues et al., 1993). Biological monitoring used to assess the health of the ecosystem and the responses of organisms to the presence of toxic substances. It also helps to estimate the actual bioavailability and toxic effects of a single chemical pollutant or a complex mixture of toxic substances (Au, 2004; Yap et al., 2011). Biological monitoring may 
rely on the measurement of changes in biomarkers, and endpoints included at the molecular, tissues, organism, and population levels (Hinton et. al., 1992; Au, 2004; El Nemr et.al., 2012; Katalay et. al., 2016).

Bivalvia is sedentary filter-feeding invertebrates, strongly affected by the surrounding environment and leads to the accumulation of toxicants and thus used as bioindicators in ecotoxicological studies (Depledge, 1998; Waykar and Deshmukh, 2011; Tüzün and Yalnı, 2017; Azizi et. al., 2018). The bivalves are also highly vulnerable to climate change, pathogens and pollutants. Clams are widely used in biomonitoring programs, and have been proven to be one of the most successful typical organisms for time-integrated responses to complex pollutant mixtures (Mona et al., 2009, 2010; Rashid et. al., 2009; Adjei-Boateng et al., 2010; Hamza, 2010; Saeedi, 2012; Wu. et al., 2013).

The gills of the bivalves perform several important functions. They play a major role in breathing. They maintain a constant current, filter the water, and collect food particles that are sorted and separated from the wastes and other suspended materials. They serve to disperse sex cells at the time of spawning and are used to incubate fertilized eggs in species with larvae. The effectiveness of these functions depends on the coordinated functioning of the gill apparatus and the contraction of the adductor muscles (Galtsoff, 1964).

In Bivalvia species, the gills and digestive glands are the first organs to be exposed to water and its pollutants (Domouhtsidou and Dimitriadis, 2000; Katalay et. al., 2016). Gill tissues are attractive models in environmental toxicological studies, due to the first site of absorption of many toxic substances in the aquatic environment. The gill filaments with their large surface area are the main interface between the organism and its environment. Thus it is constantly affected by exposure to pollutants (Balogh and Salanki, 1987; Bhavan et al., 2008). The changes in this tissue are in response to exposure to unspecified pollutants ( $\mathrm{Au}, 2004)$.

Several techniques have been used to assess the levels of pollutants in Bivalvia, including gill filaments morphology (Ballan-Dufrançais et al., 1990; Gold-Bouchot et al., 1995; Gregory and George, 2000; Gregory et al., 2002; David and Fontanetti, 2005; Nogarol et. al., 2012). In this study, scanning electron microscopy (SEM) was used to describe the morphology of the gill filaments of Tapes decussatus specimens collected from two sites. These sites differ in the degree of their pollution in order to detect potential relationships between environmental pollution due to human activity and its impact on marine organisms.

\section{MATERIALS AND METHODS}

\section{Samples Collection:}

Samples of seawater, and common clam Tapes decussatus were collected from Cleopatra shore (Marsa Matrouh) and Suez Port (Suez) in June 2019. Seawater was transported to the laboratory in plastic bottles, and alive samples of $T$. decussatus were transported in buckets of seawater.

\section{Measurements of Total Petroleum Hydrocarbons and Heavy Metals:}

Total petroleum hydrocarbons (TPHs) in surface seawater were analyzed by capillary gas chromatography (GC) followed by high-performance liquid chromatography (HPLC) with fluorescence detection. Soft body tissues of $T$. decussatus specimens were removed from shells, dried, weighed and digested individually in $30 \mathrm{ml}$ of concentrated HNO3 (APHA, 1989; O'Leary \& Breen, 1997; Rashid et. al., 2009). The specimens were dilluted into $100 \mathrm{ml}$ and filtered through 
$0.45 \mu \mathrm{m}$ membrane filter. Heavy metals including $\mathrm{Cd}, \mathrm{Co}, \mathrm{Cu}, \mathrm{Fe}, \mathrm{Mn}, \mathrm{Ni}, \mathrm{Pb}$, and $\mathrm{Zn}$ were determined in seawater, and whole soft tissues of T. decussatus using the Atomic Absorption Spectrophotometer (AAS) (Perkin- Elmer Model 2380).

Gill of Tapes decussatus Preparation for Scanning Electron Microscope:

Ten gills were separated from ten alive individuals of $T$. decussatus which collected from the two sites and fixed for morphological investigations by immersing them immediately in $4 \mathrm{~F} 1 \mathrm{G}$, phosphate buffer solution (PH 7.2) at $4^{\circ} \mathrm{C}$ overnight. The gills were then postfixed in $2 \%$ OsO4 in the same buffer at $4^{\circ} \mathrm{C}$ for 2 hours, then washed in the buffer and dehydrated at $4{ }^{\circ} \mathrm{C}$ through a graded series of ethanol, and dried. The prepared gills were mounted by using carbon paste on an Al-stub and coated with gold up to a thickness of $400 \AA$ in a sputter- coating unit (JFC-1100E). Investigations of the samples were performed in a JEOL JSM-5300 scanning electron microscope operated between 15 and 20 KV (Abdel-Salam et. al., 2014a, b)

\section{RESULTS}

Measurements of Total Petroleum Hydrocarbons and Heavy Metals:

The total petroleum hydrocarbons (TPHs) concentration in surface seawater was $0.64 \mathrm{mg} / \mathrm{l}$ in Suez Port site and undetected in Cleopatra site. The concentration of heavy metals in water and soft tissues of Tapes decussatus were at the lowest levels in Cleopatra site and recorded higher levels in the Port of Suez site (Table 1).

Table 1: Concentrations of heavy metals in surface seawater $(\mu \mathrm{g} / \mathrm{ml})$ and whole soft tissues of common clam, Tapes decussatus $(\mu \mathrm{g} / \mathrm{g}$ dry weight). (Each mean \pm standard error for 5 determinations).

\begin{tabular}{|c|c|c|c|c|}
\hline \multirow{2}{*}{ Metals } & \multicolumn{2}{|c|}{ Cleopatra (Marsa Matrouh) } & \multicolumn{2}{c|}{ Port of Suez (Suez) } \\
\cline { 2 - 5 } & Water & Soft tissues & Water & Soft tissues \\
\hline Cd & $0.010 \pm 0.005$ & $0.943 \pm 0.213$ & $0.498 \pm 0.002$ & $6.401 \pm 0.295$ \\
\hline $\mathbf{C o}$ & $0.070 \pm 0.007$ & $2.542 \pm 0.331$ & $0.991 \pm 0.041$ & $15.327 \pm 0.255$ \\
\hline $\mathbf{C u}$ & $0.078 \pm 0.008$ & $2.994 \pm 0.012$ & $4.810 \pm 0.003$ & $70.330 \pm 0.574$ \\
\hline $\mathbf{F e}$ & $0.620 \pm 0.034$ & $890.982 \pm 6.561$ & $18.016 \pm 0.008$ & $2998.450 \pm 1.880$ \\
\hline $\mathbf{M n}$ & $0.039 \pm 0.004$ & $11.114 \pm 0.235$ & $5.278 \pm 0.075$ & $96.010 \pm 0.220$ \\
\hline $\mathbf{N i}$ & $0.015 \pm 0.002$ & $3.013 \pm 0.420$ & $2.561 \pm 0.020$ & $28.345 \pm 0.373$ \\
\hline $\mathbf{P b}$ & $0.018 \pm 0.001$ & $1.772 \pm 0.441$ & $5.482 \pm 0.001$ & $53.245 \pm 2.755$ \\
\hline $\mathbf{Z n}$ & $3.921 \pm 0.043$ & $39.056 \pm 1.440$ & $18.540 \pm 0.080$ & $140.124 \pm 2.003$ \\
\hline
\end{tabular}

\section{Morphological Investigations of Tapes decussatus Gill:}

The gills of T. decussatus which collected from Cleopatra shore presented a wide surface and are easily observed in the mantle cavity. In each animal, there are two gills or ctenidia, one located on the right of the visceral mass and the other on the left. Each gill is formed by two gill-plates. These plates are the outer and inner demibranchs. The outer demibranch is shorter than the inner. Each demibranch is constituted by inner and outer lamellae arranged in a V shape, which consists of parallel ciliated gill filaments. The gill filaments of the inner and outer lamellae of each demibranch present similar morphology (Figs. 1A\& 1B).

The frontal surface of the gill filament is completely covered by cilia, called frontal, latero-frontal, and lateral cilia. The latero-frontal cilia arranged on each side of the filament and partially covered the frontal cilia. This arrangement of the laterofrontal cilia formed a fine mesh for particle retention. The lateral cilia are slightly 
longer, numerous and were inserted in the filament below the latero-frontal cilia (Figs. $1 \mathrm{C}, 1 \mathrm{D}, 1 \mathrm{E} \& 1 \mathrm{~F})$.
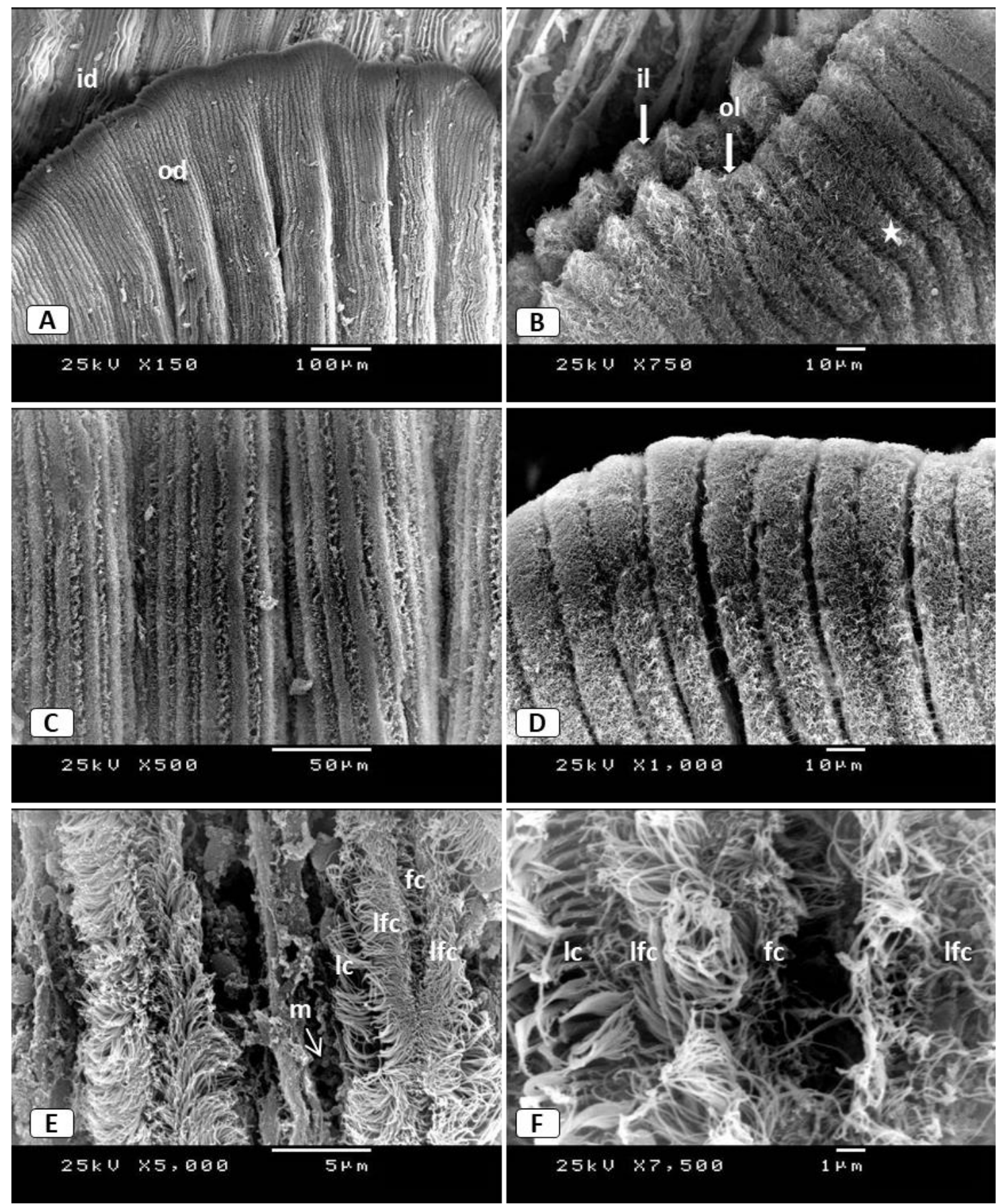

Fig. 1: Scanning electron micrographs of $T$. decussatus gill (frontal surface) collected from Cleopatra shore. (A) Inner and outer demibranch, (B) Inner and outer lamellae of the outer demibranch consist of parallel gill filaments (star), (C, D) Gill filaments with cilia and (E, F) Cilia of gill filaments. Abrr.: fc, frontal cilia; id, inner demibranch; il, inner lamella; lc, lateral cilia; lfc, latero-frontal cilia; m, mucus; od, outer demibranch; ol, outer lamella. 
Disks are formed by condensed tufts of simple cilia, which are rooted from a base extended from the lateral surfaces of the gill filaments (Fig. 2A). Drops of mucus were seen between gill filaments at the lateral and abfrontal surfaces (Figs. 1E\& 2B). Ostia scattered along the abfrontal surface of gill filaments (Figs. 2C, 2D). All the particles captured containing food particles like diatoms are conducted to a marginal groove (Fig. 2E) in the ventral region of the gill filament and then directed to the oral region. The clam eggs were observed between gill fillaments at the lateral surfaces (Fig. 2F).

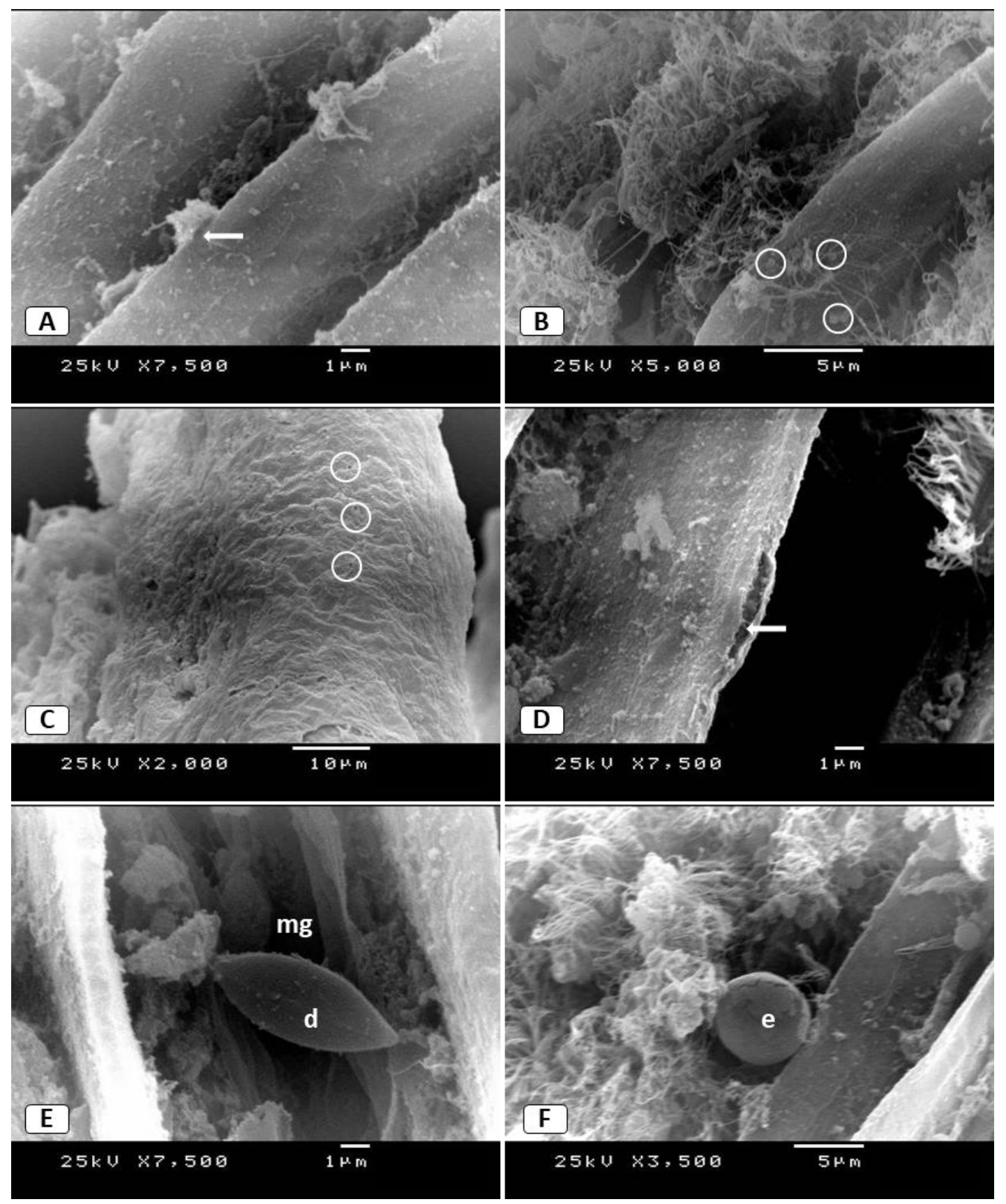

Figure 2: Scanning electron micrographs of $T$. decussatus gill collected from Cleopatra shore. (A) Disc (arrow) formed by condensed tufts of simple cilia at lateral surface of gill filaments, (B) Mucus drops (circles) at lateral surface of gill filaments, (C) Ostia distributed along the abfrontal surface of the gill filaments (circles), (D) Ostium (arrow), (E) marginal groove, (F) Egg of T. decussatus at lateral surface of the gill filaments. Abrr.: d, diatom; e, egg; mg, marginal groove. 
By comparing the morphological differences among T. decussatus samples from the two sites; the samples of Suez Port site represent increasing of the mucus that accumulated in the frontal region of the gill filaments (Fig. 3A), aggregation of particles on the ostia (Fig. 3B) and appearance of bacterial communities (Figs. 3C\& 3D) between a brick-like pattern which are formed by blocks with scabrous surfaces at the abfrontal edges of the ascending lamellae, primarily adjacent to the marginal groove. Other morphological structures are similar in the gills from the two sites.
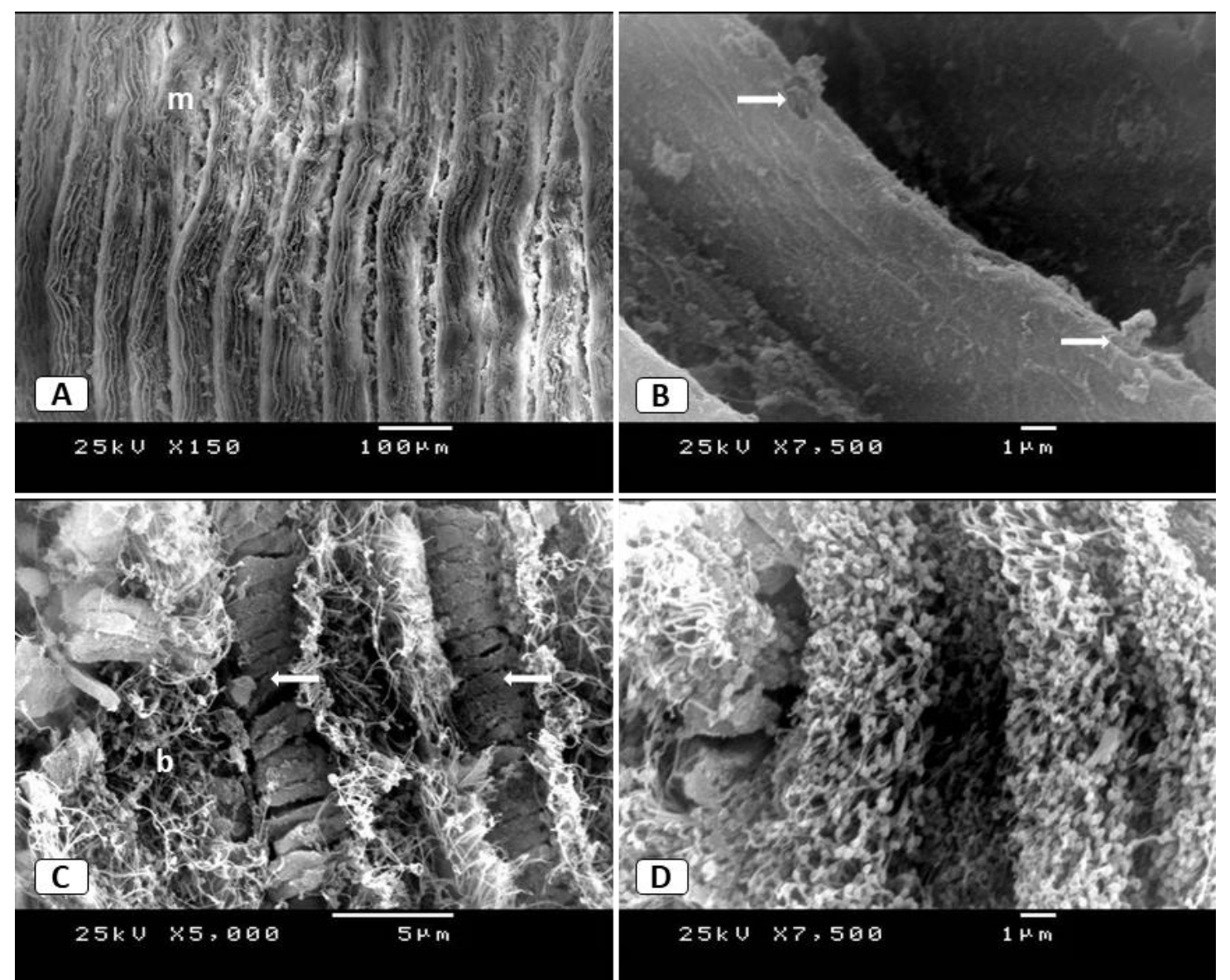

Fig. 3: Scanning electron micrographs of $T$. decussatus gill collected from Suez

Port. (A) Frontal surface of gill filaments showing increasing in mucus, (B) Aggregation of particles on the ostia at the abfrontal surface of the gill filaments (arrows), (C) An ascending lamella showing a series of brick-like structures on the abfrontal edges; (D) Bacterial communities. Abrr.: b, bacteria; m, mucus.

\section{DISCUSSION}

Total petroleum hydrocarbons (TPHs) were recorded high value at Suez Port (Suez) while not detected at Cleopatra shore (Marsa Matrouh), this is due to the passage of ships through Suez Canal which transport petroleum oil from the Red Sea to the Mediterranean Sea and waiting for transit through Suez Port (Hamed and Emara, 2006; Hamza, 2010), so this Port had seawater TPHs concentration higher than that of Cleopatra region.

Concerning the sites variations, the highest values of $\mathrm{Cd}, \mathrm{Cu}, \mathrm{Fe}, \mathrm{Mn}, \mathrm{Ni}$ and $\mathrm{Pb}$ concentrations in water and T. decussatus soft tissues were recorded at Suez Port. These high concentrations may be attributed to sewage and wastes discharge from the city of Suez and ships awaiting transit through the Suez Port. Also, Suez receives 
waste effluents from the industrial complex, which includes oil refineries, fertilizers company, and power stations. Also, a remarkably high concentration of $\mathrm{Cu}$ at Suez may be due to corrosion of ships' hulls coatings and anti-fouling paints as stated by Hamed and Emara (2006) and Hamza (2010).

Cleopatra shore (Marsa Matrouh) recorded the lowest values of heavy metals in surface seawater and whole soft tissues of Tapes decussatus. So, this area is unpolluted from detected heavy metals and we can use it as a control site.

It was found that heavy metals concentrations in $T$. decussatus soft tissues were higher than in water; these are attributed with the fact that clams are bioindicators which accumulate contaminants in their bodies in levels much higher than in the surrounding environment as reported by (Farag et al., 2000; Cravo et al., 2004; ElGamal and Sharshar, 2004; Hamed and Emara, 2006; Hamza, 2010; Azizi, 2018).

The position and distribution of the cilia seen here in the frontal region of $T$. decussatus gill filaments were the same as reported in other bivalves such as Mytilus edulis (Riisgard et. al. 1996), Perna perna (Gregory and George, 2000), Mytella falcata (David and Fontanetti, 2005) and Lithophaga lithophaga (Aksit and Mutaf, 2014). The lateral cilia are responsible for pumping water into the bivalve shell and latero-frontal cilia are clearly important for particle retention by filter feeding bivalves, as discussed previously (Moore, 1971; Jones et. al., 1990; David and Fontanetti, 2005). Silvester (1988) stated that efficient pumping of water occurs when the cilia occur in high densities, such as in the band of lateral cilia on the gill filaments of M. edulis. Dufour and Beninger (2001) stated that the abfrontal surface is a vestigial mucociliary epithelium and that the different distributions of cilia and mucocytes seen on the abfrontal surfaces of bivalve gills result from selective forces that vary in nature and degree. This study demonstrates a distribution of cilia similar to other bivalves (David and Fontanetti, 2005; Aksit and Mutaf, 2014). Gregory et al. (1999) studied the morphology of Perna perna gill filaments exposed to different concentrations of mercury and found some alterations that included loss of abfrontal cilia and an increase in the number of cilia on the lateral surface. These authors suggested that this increase in cilia was an attempt to enhance the circulation of water, thereby increasing the rate of filtration and gill oxygenation. In this study, the cilia were covered by mucus.

The blocks with a scabrous surface present in the slits next to the marginal groove and between the tissue junctions of the lamellae are assumed to grate captured food particles that are large relative to the size of the aperture through which they must enter into smaller pieces to be molded with mucus and consumed by the bivalve as stated by Aksit and Mutaf (2014).

The role of mucus in food transportation has been extensively studied. Beninger and St-Jean (1997) concluded that mucus has an important role in selecting particles that will be ingested and those that will be rejected. Studies with fish and bivalves exposed to metals have reported an increase in the production of the mucus that covers the body and gills (Jagoe and Haines, 1997; David and Fontanetti, 2005). This increased mucus production may serve as a protective barrier to pollutants, as a binding site to capture heavy metals before they can damage the tissue, or as a means of expelling pollutants absorbed by secretory and other cells as stated by David and Fontanetti (2005). Several studies found a relation between the mucus secretion in marine invertebrates and the growth of bacterial communities and other microorganisms (Pascal and Vacelet, 1981; Kim, 1994; Abdel-Salam, 2014a).

In conclusion, the high level of TPHs and heavy metals in Suez Port site could explain the increased mucus production in specimens which were collected from this site, the mucus providing protection against these pollutants. Bacterial communities 
were observed in gills of specimens collected from Suez Port due to the increase of mucus. There were no significant morphological alterations in the gill morphology of clams from different sites. This lack of variation may reflect a long-term adaptation of this bivalve to chronic exposure to pollutants.

\section{REFERENCES}

Abdel-Salam, H.A.; Abdel-Badeea, S.M.; Hamza, D.S.; Ali, A.A.M. and EL Shaarawy, H.I. (2014a). Ultrastructure of Galaxea fascicularis from El-Ain El-Sukhna, Gulf of Suez Red Sea. International Journal of Development, 3(1): 9-21.

Abdel-Salam, H.A.; Khalil, N.Kh.; Hamza, D.S. and Ali, A.A.M (2014b). The structure of the reef building coral Acropora humilis and associated Bioeroding microorganisms from Gulf of Suez- Red Sea. International Journal of Development, 3(1): 101-114.

Adjei-Boateng, D.; Obirikorang, K.A. and Amisah, S. (2010). Bioaccumulation of Heavy Metals in the Tissue of the Clam Galatea paradoxa and Sediments from the Volta Estuary, Ghana. Int. J. Environ. Res., 4(3): 533-540.

Aksit, D. and Mutaf, B.F. (2014). The gill morphology of the date mussel Lithophaga lithophaga (Bivalvia: Mytilidae). Turk. J. Zool., 38: 61-67.

APHA. (1989). Standard Methods for the Examination of Water and Wastewater (17th. ed). Washington: American Public Health Association. American Water Works Association. Water Pollution Control Federation.

$\mathrm{Au}$, D.W.T. (2004). The application of histo-cytopathological biomarkers in marine pollution monitoring, a review. Marine Pollution Bulletin, 58, 817-834.

Azizi, G.; Akodad, M.; Baghour, M.; Layachi, M. and Moumen, A. (2018). The use of Mytilus spp. mussels as bioindicators of heavy metal pollution in the coastal environment. J. Mater. Environ. Sci., 9 (4), 1170-1181.

Ballan-Dufrançais, C.; Jeantet, A.Y. and Coulon, J. (1990). Cytological features of mussels (Mytilus edulis) in situ exposed to an effluent of the titanium dioxide industry. Ann. Inst. Océanogr. 66, 1-17.

Balogh, K.V. and Salanki, J. (1987). Biological monitoring of heavy metal pollution in the region of Lake Balaton, (Hungary). Acta Biol. Hung, 38, 13-30.

Beninger, P.G. and St-Jean, S.D. (1997). The role of mucus in particle processing by suspension-feeding marine bivalves: unifying principles. Mar. Biol. 129, 389397.

Bhavan, P.S.; Yamuna, A. and Geraldine, P. (2008). Mercury induced metabolic changes in the juveniles of the economically important freshwater prawn Macrobrachium malcolmsonii. The Asian J. Anim. Sci., 3, 6065.

Cravo, A.; Bebianno, M.J. and Foster, P. (2004). Partitioning of trace metals between soft tissues and shells of Patella aspera. Env. Int., 30(1): 87- 98.

David, J.A. and Fontanetti, C.S. (2005). Surface morphology of Mytella falcate gill filaments from three regions of the santos estuary. Braz. J. morphol. Sci., 22(4), 203-210.

Depledge, M.H. (1998). The ecotoxicological significance of genotoxicity in marine invertebrates. Mutat. Res. 399, 109-122.

Domouhtsidou, G.P. and Dimitriadis, V.K. (2000). Ultrastructural localization of heavy metals $(\mathrm{Hg}, \mathrm{Ag}, \mathrm{Pb}$ and $\mathrm{Cu})$ in gills and digestive gland of mussels, Mytilus galloprovincialis (L). Archives of Environmental Contamination and Toxicology 38: 472-478. 
Dufour, S.C. and Beninger, P.G. (2001). A functional interpretation of cilia and mucocyte distributions on the abfrontal surface of bivalve gills. Mar. Biol. 138, 295-309.

Dybern, B. (1983): Field sampling and preparation of subsamples of aquatic organisms for analysis of metals and organochlorines, FAO, Fisher Tech. Paper, 212: 113.

El Nemr, A.; Khaled, A.; Mouneer, A.A. and El Sikaily, A. (2012). Risk probability due to heavy metals in bivalve from Egyptian Mediterranean coast. Egyp. J. of Aquat. Res, 38, 67-75.

El-Gamal, M.M. and Sharshar, Kh. M. (2004). Heavy metals partitioning between soft tissues and shells of some freshwater and marine mollusks as accumulation indicators for their monitoring in the environment. Egy. Ger. Soc. Zool., 45 (D): 141-161.

Farag, E.A.; Dekinesh, S.I. and El- Odessy, H. (2000). Trace elements accumulation in soft parts of six edible bivalve molluscs inhabiting Alexandria coast, Egypt. Egy. Ger. Soc. Zool., 31 (D): 27-36.

Galtsoff, P.S. (1964). The American Oyster Crassostrea virginica Gmelin. Fishery Bulletin, v. 64. United States Government Printing Office, Washington, D. C. ISSN 0090-0656; e-ISSN 1937-4518

Garrigues, P.; Narbonne, J.F.; Lafaurie, M.; Ribera, D.; Lemaire, P.; Raoux, C.; Michel, X.; Salaun, J.P.; Monod, J.L. and Romeo, M. (1993). Banking of environmental samples for short-term biochemical and chemical monitoring of organic contamination in coastal marine sediments: the GICBEM experience (1986- 990). Sci. Tot. Environ., 139/140, 225-236.

Gold-Bouchot, G.; Simá-Alvarez, R.; Zapata-Pérez, O. and Güemez-Ricalde, J. (1995). Histopathological effects of petroleum hydrocarbons and heavy metals on the American oyster (Crassostea virginica) from Tabaco, Mexico. Mar. Pollut. Bull. 13, 439-445. 9.

Gregory, M.A. and George, R.C. (2000). The structure and surface morphology of gill filaments in the brown mussel Perna perna. Zool. Afr. 35, 121-129. 10.

Gregory, M.A.; George, R.C.; Marshall, D.J.; Anandraj, A.; McClurg, T.P. (1999). The effects of mercury exposure on the surface morphology of gill filaments in Perna perna (Mollusca: Bivalvia). Mar. Pollut. Bull. 39, 116-121.

Gregory, M.A.; Marshall, D.J.; George R.C.; Anandraj, A.; McClurg, T.P. (2002). Correlations between metal uptake in the soft tissue of Perna perna and gill filament pathology after exposure to mercury. Mar. Pollut. Bull. 45, 114-125.

Gregory, M.A.; Marshall, D.J.; George, R.C.; Anandraj, A. and McClurg, T.P. (2002). Correlation between metal uptake in the soft tissue of Perna perna and gill filament pathology after exposure to mercury. Marine Poll. Bull. 45: 114-125.

Hamed, M.A. \& Emara, A.M. (2006): Marine molluscs as biomonitors for heavy metal level in the Gulf of Suez, Red Sea. Mar. Syst., 60: 220-234.

Hamza, D.S. (2010). Genetic diversity and structural variations of some clams (Family: Veneridae). PhD Thesis, Benha University.

Hinton, D.E.; Baumann, B.C.; Gardner, G.R.; Hawkins, W.E.; Hindricks, J.D. and Murchelano, R.A. (1992). Biomarkers: biochemical, physiological, and histological markers of anthropogenic stress. Lewis, Boca Raton., p, 347.

Jagoe, C.H. and Haines, T.A. (1997). Changes in gill morphology of Atlantic salmon (Salmo salar) smolts due to addition of acid and aluminum to stream water. Environ. Pollut. 97, 137-146. 
Jones, H.D.; Richards, O.G. and Hutchinson, S. (1990). The role of ctenidial abfrontal cilia in water pumping in Mytilus edulis L. J. Exp. Mar. Biol. Ecol. 143, 1526.

Katalay, S.; Yavaşoğlu, A.; Yiğittürk, G.; Oltulu, F.; Sarı, G. and Yavaşoğlu, N.U.K. (2016). Histological effects of pollution on gill and hepatopancreas of black mussles (M. galloprovincialis L.) from Izmir Bay of Turkey. Fresenius Environmental Bulletin, 25(5), 1460-1466.

Kim, K. (1994). Antimicrobial activity in gorgonian corals (Coelenterata, Octocorallia). Coral Reefs, 13 (2): 75- 80.

Mona, M.; El-Gamal, M. and Hamza, D. (2010). Population genetic variation and species relationships of seven clams species (Family: Veneridae) from Lake Timsah (Suez Canal). INOC-Tischreen University, International conference on Biodiversity of the Aquatic Environment, 611-622.

Mona, M.H.; El-Gamal, M.M. and Hamza, D.S. (2009). The population genetic structure of Tapes decussates (Veneridae: Bivalvia) collected from contaminated and uncontaminated coastal waters in Egypt. Egypt. J. Zool., 53: 175-189.

Moore, H.J. (1971). The structure of the latero-frontal cirri on the gills of certain lamellibranch molluscs and their role in suspension feeding. Mar. Biol. 11, 23-27.

Nogarol, L.R.; Brossi-Garcia, A.L.; David, J.A. and Fontanetti, C.S. (2012). Morphological and histochemical characterization of gill filaments of the brazilian endemic bivalve Diplodon expansus (Küster, 1856) (Mollusca, Bivalvia, Hyriidae). Microsc. Microanal. Page 1-9.

O'Leary, C. and Breen, J. (1997). Metal level in seven species of mollusc and in seaweeds from the Shannon Estuary: Biology and Environment: Proceeding of the Royal Irish Academy. 97: 121-132.

Pascal, H. and Vacelet, E. (1981). Bacterial utilization of mucus on the coral reef of Aquaba (Red Sea). Proc 4th Int. Coral. Reef. Symp., 1:669-677.

Rashid, A.W.; Vun, L.W. and Abdullah, M.H. (2009). Accumulation and Depuration of Heavy Metals in the Hard Clam (Meretrix meretrix) Under Laboratory Conditions. Journal Biosains, 20 (1), 19-26,

Riisgard, H.U.; Larsen, P.S. and Nielsen, N.F. (1996). Particle capture in the mussel Mytilus edulis: the role of laterofrontal cirri. Mar. Biol. 127, 259-266.

Saeedi, H. (2012). Availability of Venerid Clam, Amiantis umbonella as potential metal bioindicator in Bandar Abbas coast, the Persian Gulf. The Egyptian Journal of Aquatic Research, Volume 38, Issue 2, 2012, Pages 93-103.

Silvester, N.R. (1988). Hydrodynamics of flow in Mytilus gills. J. Exp. Mar. Biol Ecol. 120, 171-182.

Stewart, I.T.; Cayan, D.R. and Dettinger, M.D. (2004). Changes in snowmelt runoff timing in western North America under a 'business as usual' climate scenario. Climatic Change, 62, 217-232.

Tüzün A. and Yalnız, S.E. (2017). Use of mollusc species as bioindicators in water pollution. Conference: VIII. International Symposium on Ecology and Environmental Problems (ISEEP-2017) At: Çanakkale, Turkey

Waykar, B.B. and Deshmukh, G. (2011). Evaluation of bivalves as bioindicators of metal pollution in freshwater. Bulletin of Environmental Contamination and Toxicology, 88(1): 48-53. 
Wu, H.; Ji, C., Wang, Q.; Liu, X.; Zhao, J. and Feng, j. (2013). Manila clam Venerupis philippinarum as a biomonitor to metal pollution. Chinese Journal of Oceanology and Limnology. 31, 65-74.

Yap, C.; Azmizan, A. and Hanif, M. (2011). Biomonitoring of trace metals ( $\mathrm{Fe}, \mathrm{Cu}$, and $\mathrm{Ni}$ ) in the mangrove area of peninsular Malaysia using different soft tissues of flat tree oyster Isognomon alatus. Water Air Soil Pollut., 218, 1936. 